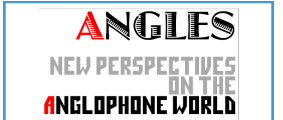

\section{Angles}

New Perspectives on the Anglophone World

3 | 2016

Angles and limes

\title{
Racism and Violence in Gar Anthony Haywood's P. I. Fiction
}

\section{Nicole Décuré}

\section{(2) OpenEdition}

1 Journals

\section{Electronic version}

URL: https://journals.openedition.org/angles/1736

DOI: 10.4000/angles.1736

ISSN: 2274-2042

\section{Publisher}

Société des Anglicistes de l'Enseignement Supérieur

\section{Electronic reference}

Nicole Décuré, "Racism and Violence in Gar Anthony Haywood's P. I. Fiction", Angles [Online], 3 | 2016, Online since 01 November 2016, connection on 07 June 2022. URL: http://journals.openedition.org/ angles/1736 ; DOI: https://doi.org/10.4000/angles. 1736

This text was automatically generated on 7 June 2022.

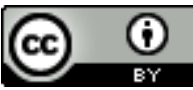

Angles est mise à disposition selon les termes de la Licence Creative Commons Attribution 4.0 International. 


\title{
Racism and Violence in Gar Anthony Haywood's P. I. Fiction
}

\author{
Nicole Décuré
}

1 Chester Himes wrote in his autobiography: "the detective story [...] is an American form. So I haven't created anything whatsoever, I just made the faces black, that's all" (Soitos 141). Himes certainly underestimated (or was being modest about) himself and his own importance in crime fiction. Although there had been African American writers of detective fiction before him ${ }^{1}$ they wrote little and have been all but forgotten. Himes was a far more prolific writer and acquired some fame as a black noir writer. It took forty more years for black crime fiction writers to follow in his footsteps and introduce new black faces in the detective story. By then, of course, much had changed. The Civil Rights Movement had left an indelible imprint on American society, "Black Power" and "Black is beautiful" had become world-known slogans, Martin Luther King Jr. and Malcolm X had fought and died, Shirley Chisholm had run for president, AfricanAmericans had become first-class citizens... and President Bill Clinton was about to acknowledge Walter Mosley as one of his favourite writers.

Gar Anthony Haywood was born in 1954, three years before Chester Himes published the first of his ten-book Harlem series, For Love of Imabelle. Haywood's first detective novel, Fear of the Dark, appeared in 1988, four years after Himes died. So it can be said that Haywood was the African-American writer who started the nineties' wave of crime fiction written by black authors and featuring a black protagonist, preceding Walter Mosley by two years (Devil in a Blue Dress was published in 1990). Then, black women such as Nikki Baker (In the Game, 1991), Eleanor Taylor Bland (Dead Time, 1992) Yolanda Joe (Falling Leaves of Ivy, 1992) and Barbara Neely (Blanche on the Lam,1992) came on the scene, followed by many others, more women than men (Décuré 1999, 2001) - different times, different books, different "blackgrounds" as defined by Stephen Soitos (37). Aaron Gunner, Haywood's recurrent hero, is a private detective, fashioned after Peter Gunn (hence the name), a white TV series character. However, the first name Aaron was not chosen with any reference to Moses' brother in the Bible but just because it "sounded right to [my] ear." His creator acknowledges his debt to Ross MacDonald 
who, according to him, made an art form out of the P. I. novel ${ }^{3}$ (Haywood's website) rather than to Himes. Indeed, Gunner reminds us more of Marlowe and Archer than of "Coffin Ed" Johnson and "Grave Digger" Jones. The series, to date, comprises six novels published between 1988 and 1999 and three short stories. Haywood has written another series featuring a retired couple, Joe and Dottie Loudermil, as heroes and comprising three novels so far. He has also written a handful of standalone thrillers under a different pen name.

\section{Aaron Gunner, a black P. I. of "good conscience"}

As soon as he appears, in chapter 2 of Fear of the Dark (1988), Gunner is described as a "black man" (4). All we are going to learn about his physique is contained in these first lines: he weighs 208 pounds, and has been bald for a few years (thus resembling the author):

The tired lines beneath his sharp brown eyes were still there, and the stubble that grew overnight along the soft angles of his chin was getting harder to see every day -because it was white, as in grey, as in dying a slow death. Gunner was not an old man, but his was a face of charm worn down by thirty-four years of exhaustion, a handsome parchment of flesh he carried like a ledger filled with dreams that had died hard and hopes he had never coaxed off the ground. (Fear of the Dark 8)

Thirty-four is young to be feeling so old, disillusioned and world-weary. In fact, in a subsequent book, we read that Gunner is just over 40. After that first and last description, we only perceive Gunner as a mind (and a heart) and, sometimes, an aching body after a fight.

Gunner is a typical P. I. who cannot really make a living at his "trade," a loner with little private life, few friends (but of all races), no family to speak of, no ties of any sort: even the dog that is foisted on him at one point to alleviate his loneliness quickly disappears from the scene. He occasionally seduces a woman (or is seduced by one). Although he always manages to discover the truth, Gunner, like most hard-boiled P. I.s, goes about it in a rather fumbling way, making mistakes, feeling stupid, overlooking important clues, misjudging danger and people, getting into fights, getting bashed on the head, shot at, and abducted countless times. He is not averse to using violence himself, contributing his fair share to the fairly high body count in the novels.

Gunner is not the narrative voice, but when he is on the scene-and he always is, except for the first chapter of each book-events are narrated from his point of view; the comments come from the narrative voice rather than the authorial voice. And his point of view is given freely and abundantly, especially on issues that are of concern to Haywood who said, in a 2003 interview, that the crime/mystery genre was the best medium through which to make commentary about the world around us, adding: "Internally, my characters are very much reflections of myself" (Jordan). Thus, it is difficult to separate Gunner's expressed opinions from Haywood's. The third-person narrative is an attempt at neutrality but, although author and character have very different lifestyles, it cannot conceal the author's personal opinions.

7 Haywood sees it as his responsibility, as a "black author of good conscience," to counteract negative images of black people by proposing a "more accurate and less sinister picture of black people to the reading public" (Bailey 122). As "prejudice is abundant and here to stay," black writers "will never want for material" and will keep 
on writing in this vein. At the same time, he refuses stereotyping. "We're all individuals, all completely different and we make up who we are as we go, and the fact of the matter is none of us will ever create the African American character because the African American spirit is too varied" (Julien \& Mills 195).

Haywood wants to make the readers go places they have never been to (Ibid. 189), he wants to make them think. "I want them to have questions at the end [...] I want them to be asking questions that they never have asked themselves before" (Ibid. 198-9). He wants to raise their consciousness, to educate them.

But see, such was, and continues to be, the state of most people's ignorance of the black man's plight in America. Nobody ever sees our shit coming, because they aren't even aware of our constant proximity to The Edge, that precipice of insanity to which we are regularly and systematically subjected (Haywood, 2002).

\section{Racism}

Most of the questions Haywood raises concern racism and violence. The first novel, Fear of the Dark (1988), is set against a background of social violence with a threat of racial explosion, anticipating the 1992 riots in Los Angeles after Rodney King's beating by the police. The plot revolves around black militants and white racists. Not Long for this World (1990) deals with gangbanging as a lethal mode of life among black teenagers in South Central L.A. You Can Die Trying (1993) examines the (bad) relations between the white police and the black community, and inter-relations between blacks and Asians, especially after the riots. It's not a Pretty Sight (1996), while still addressing race issues, is strongly focused on violence against women. When Last Seen Alive (1997) discusses black people's moral responsibility towards their community and introduces a black extremist group fighting Uncle Tomism through executions. Finally, All the Lucky Ones Are Dead (1999) takes up this thread again while broaching the subjects of AIDS and homophobia. The issue of racism is omnipresent in Haywood's Gunner series. It is denounced, criticised, fought against, in word and in deed. The title of the first novel is revealing in this respect. "Fear of the dark" alludes to white people's hatred of not understanding something and black people are part of that fear: whites do not understand blacks. It can also be read as "fear of blacks" themselves.

In Haywood's fictional world, Gunner became a P. I. in 1974 over the issue of racism: he was training at the police academy when he witnessed a racist attack on a cadet, socked the instructor and got kicked out. He is the only black P. I. in town which explains why his clients are black too. Although Haywood clearly has an axe to grind with racists (whatever the colour of their skin), not all whites are bad and not all blacks are goodfar from it-mostly perhaps because there are few white characters in the stories which are set in a mostly black neighbourhood. The whites that acquire some personality are rather unprejudiced persons, like Poole, the "decent" (You Can Die Trying 23) white lieutenant who becomes Gunner's friend (with a little distance), or a woman public defender for whom he works. Furthermore, in the third novel of the series, Gunner tries to find the truth behind what seems to be a clear-cut case in the aftermath of Rodney King's beating and the change of policy in the LAPD: a white policeman, a "nightstick-happy nigger hater" (Ibid. 45), shot a black kid and, later, killed himself. Gunner sets out to prove that it was the white man who was, in fact, first shot at, and that he fired back in self-defence. 
11 The issue of racism in the police runs strongly in this book. Recent debate in the United States, in the wake of the 2014 Ferguson killing, unrest and subsequent turmoil, shows us that there is still a long way to go. The harassment of black people by the police is condemned, of course. Even Gunner feels nervous around them although he may understand some aspects of the problem: cops do a hard job, "being a cop's a dirty business" (Ibid. 207), and police find it difficult to deal with the hatred they generate. Gunner does not go for Manichean explanations and tries to get to the root of the problem.

He had never gone in for the popular dictum that said no cop was to be trusted and every cop was to be feared, but he had seen enough uniformed madmen in his time to know that his next confrontation with a policeman could always be his last. A run-in with the wrong cop, at the wrong time, was all that it would take. Because many of the men and women who patrolled these streets didn't always see things the way they really were. They didn't think they could afford to. In the interests of staying alive, they had taught themselves to expect the worst of every situation, and to treat strangers like the enemy. It was experience-driven paranoia, coupled with a vast array of preconceived notions about whole groups of people. Notions that could get a man belonging to such a group killed or crippled for life under the right set of circumstances. (Ibid. 101-2)

The more militant, accusatory attitudes are well expressed in the books through secondary characters' analyses. They are generally voiced in a confrontation with Gunner's more nuanced opinions: although he may agree that the African-American community is oppressed in many ways, the world is not black and white, people have to be judged as individuals and not as part of a group. Truth and the law are values that rise above all considerations. Truth matters and Gunner does not "care who it condemns or vindicates" (Not Long for this World 42), and there is only one law, however unjust it may be. The police only see the bad side of humanity (crime, drugs, violence) and tend to lump everybody into the same category. They come to hate people and be afraid of them, and people, in return, hate them and are afraid of them. Gunner argues that the forest must not hide the trees. "You can die trying" expresses the difficulty of the task: staying alive, trying to do the right thing. The situation seems pretty hopeless, a vicious circle, a "no-win" situation.

[...] you had to prove more than your mere innocence when you were unfortunate enough to come up against [the police]; you had to prove your worth as a human being first, before anything else. Because the system in which they operated had taught them to question not only your good intentions but your right to be considered their equal, as well. Along with all the amusing names they liked to use for you came any number of misconceptions, and all you had to do to get along with them was dispel those misconceptions one by one, time and time again.

While the hell that was their daily bread out on the street kept reinforcing all their fears and misconceptions against you. (Ibid. 211)

But there is still a tenuous hope that things might get better. "It was not inconceivable" (Ibid.).

Racism is a serious issue but it can also be denounced with levity. To a white woman who tells him he doesn't sound black over the phone, Gunner retorts sarcastically: "So I've been told [...] Must be all those big words I use. Like who, what, and where" (Fear of the Dark 102). Language is important. Words are not innocuous. Repeatedly, Gunner will fight against the matter-of-fact use of racist words like "nigger" or sexist ones like "bitch." 
Black men and women who threw the n-word around [...] were too short on brain cells to appreciate how they were embracing one of the most powerful and dehumanizing weapons ever used against their own people. They liked to say that the twist they put on the way it was spelled and pronounced made something harmless out of it, but the truth was, it just made them feel better for having bought into the white man's contention that it was a perfectly suitable name for them.

Funny, Gunner thought, but the Japanese never did take to "Jap" that well. Nor the Jews to "kike." Nor... (It's not a Pretty Sight 131)

Gunner explains the importance of words to a child: "Most of the hate in this world starts with one thing [...] Names. The names we give ourselves, and the names we give to others. I'm talking about ugly names. Names like nigger and kike, and faggot and gook-and bitch and ho. Names like that. Names that do nothing but hurt people, and degrade people" (Ibid. 240).

When the message is not heard, he resorts to violence to be understood, first knocking unconscious a young man with the butt of his gun and then shooting a bullet through a rapper's calf. "He really had heard all the four-letter vitriol he could stand in one afternoon" (All the Lucky Ones are Dead 111). Such methods are hardly compatible with the principle of tolerance but then we are in a world of fantasy, and while this violence seems a trifle unrealistic, it certainly expresses wishful thinking, the cathartic desire to make a point forcefully, knowing that one will not be able to act upon this kind of impulse in real life.

Daily acts of racism, racist attitudes and innuendoes are rarely overlooked (Fear of the Dark 44-5). Gunner does not let these go. He says to a white policeman who does not believe him: "Look. Believe what you want to believe [...] You want to assume because I'm a soul brother, I must be lying to you, that's your privilege. And your hang-up" (You Can Die Trying 44). But then, soon after, a similar act of racism against whites is exposed. Although despising racism, denouncing the differential treatment of blacks and whites, Gunner has no patience with black so-called revolutionaries. He sees black politicians, as they appear in the novels, as opportunistic and insincere, only out for the money and personal power. The Black Muslims are disposed of in a few scathing words. Louis Farrakhan, the leader of the Nation of Islam, "keynote speaker and chief organizer" of the Million Man March is presented as "brilliant and inspired one moment, delusional and paranoid the next" (When Last Seen Alive 2). Two extremist groups are portrayed as dangerous: the Brothers of Volition, patterned after the Black Panthers, in the first novel, and the Defenders of the Bloodline, intent on "ridding the black race of all Uncle Toms" (Ibid. 108) in the last two novels of the series. Both appellations are ridiculous in themselves. He certainly disagrees with the idea of a violent revolution, which he considers as "unabated madness" (Fear of the Dark 181): "We've spent a hundred and fifty years trying to prove to the White Man that we can handle civilization just as easily as he can, and you want to wipe that out in a week. I don't get it" (Ibid.180).

These are the late 80s and early 90s. The black middle-class now has a lot more to lose. Gunner prefers "enlightenment" of white people to confrontation: "Terry Alison was shown that a dinner date with a given black man could be as thought-provoking and stimulating as one with a given man of any other race, colour, or creed" (Ibid. 185). Gunner declares himself apolitical (Ibid. 74), a position that enables him to criticize everything and everybody. 
Gunner was far from a political animal-his idea of political activism was endorsing at least one petition worthy of his signature annually-but the oxymoron that was black archconservatism had always been able to get a rise out of him. It was simply a concept he didn't get. African-Americans like himself sharing ideologies with the far right [...] But then, people had a right to believe whatever they wanted to believe, and no one was more willing to grant them the privilege than Gunner, with the single proviso that all their propagandizing be done outside the range of his faculties. Suffering the company of fools was something the investigator did best only from a distance, though this wasn't always possible. (All the Lucky Ones are Dead 8)

19 Gunner claims independence from the black community in matters of race. He feels he is his own master and refuses to be held accountable for his thoughts and actions. This is the black man's burden that no white man ever has to shoulder: "I'm an American. Keeping my reasons for doing the things I do to myself is my God-given birthright [...] I wage my own wars" (You Can Die Trying 118)-which he does, for example by defending Korean shopkeepers in the face of black hostility during and after the L.A. riots. It is strange that Gunner, who, most of the time, is not a believer, should refer to God and not to the Constitution. He is accused of Uncle Tomism because he defends a white racist. But to him, truth is above these considerations. This also applies to battery. Although it would be convenient to accept that a husband killed his wife, Gunner prefers to find out what really happened. His ambivalence is also felt in the discussion about gangsta rap in All the Lucky Ones are Dead: he doesn't like it and doesn't understand how anyone might like it, but he is ready to defend is as socially relevant.

Haywood's concerns are not limited to the plight of African Americans. Other minority groups get his attention-Asians, Latinos, Jews-as well as gays and women, with a particular emphasis on homophobia, which he believes is rampant in the black community, as well as on what he perceives are difficult relations between black men and women.

\section{Violence}

Perhaps more damning than racism in Gunner's eyes is violence within the black community because it is self-destructing "in our little war-torn corner of the world" (Not Long for this World 15). Black men kill black men. Gunner says of gangbangers, those “juvenile fraternities of terror" (Ibid. 1): "I don't much like their manners, or the heavy iron they're so fond of demonstrating in public places. They kill children in sandboxes and grandmothers on porch swings in the never-ending process of killing themselves, and that kind of fatal inefficiency pisses me off no end" (Ibid. 14-5). Gunner's way of dealing with this, again, is to stand aside. He is called "an amateur in a fucking war zone" (Not Long for this World 128). "Theirs was a dance of death, pointless and seemingly without end, and only a fool or a hero would expose himself to the insanity of it anymore than his everyday circumstances already demanded" (Ibid. 71-2).

As with racism, sometimes a humorous comment is enough to denounce the prevalence of violence in society. Anybody can wield a gun. "If she could pull the trigger, she could get the job done, and if she had ever watched ten minutes of prime-time television, she could pull the trigger. In her sleep" (Fear of the Dark 12). Violence is deeply ingrained in the political and economic systems. Gunner declares, at one point, that the entertainment industry "sells" violence. He feels a "mild revulsion" in a gun shop at 
the sight of young people and "innocuous" grandfathers, ordinary citizens freely buying "tools of death" (Not Long for this World 33-5).

"Not long for this world," the title of the second novel, describes the hopelessness, the waste of this way of life. "All the lucky ones are dead," another title, also indicates that living in such a violent environment is not the best option. Historical, social, political and psychological explanations are given to explain gangbanging and, at the end, Gunner's "blissfully blind hatred," his "pure, uncomplicated abhorrence" of this phenomenon has abated somewhat because he can now understand how it came about in the "bleak, soul-crushing, and heartbreaking [...] L. A. street-gang culture" (Ibid. 180-1). Gunner's attitude varies between a desire to "reform" the delinquents, which he does not always act upon for fear of being rejected and because it is too late anyway (You Can Die Trying 115) and a belief that things can change, that violence is not inevitable. Individuals can make choices, can decide whether they want to be gangbangers or respectable citizens. When he gets involved with a six-year-old thief and tries to change him, he acts upon this belief that, perhaps, the worst can be avoided.

But Gunner's behaviour contradicts his principles. While deploring so many deaths, he himself is no angel of mercy. He does not feel safe without a gun. He threatens people with physical violence, he hits men and women although he claims he has never beaten a woman. He kills in self-defence but he is also ordered to kill (or be killed himself) and even once orders somebody to kill in his stead. He gets into fights at least three times per book. He is kidnapped, hurt in many ways. And still, like any phoenix-like P. I., he rises, none the worse for the wear and tear, ready for more "little war games, wisdom be damned, in pursuit of some non-existent, macho concept of self-respect, and for what?" This question is asked by a black woman whom Gunner falls in love with. And she adds another crucial question: "What do you ever gain that's more valuable than all that you lose?" (Not Long for this World 137). Sometimes, Gunner does realise that his course of action is rarely smart, that he is careless, that he plays games of "oneupmanship" (Ibid. 204), that he acts out of "reckless machismo" (When Last Seen Alive 159). It is in his relations with some women that the anti-hero appears best. He is not good at sustaining relationships and, above all, most of the time, he is not a fantastic lover, even in his dreams, something that no P. I. ever admits. And this is probably the most innovative feature of Haywood's fiction.

\section{Conclusion}

A male African American writer of detective fiction remains a rarity to this day. Few names come to mind. Himes, of course, and Walter Mosley. We can also cite Robert Greer, Hugh Holton or Gary Phillips. Could we apply to male black crime fiction Munt's analysis on women's crime fiction and argue that the genre is alien to black consciousness because it "is not a logical choice for those positioned outside the hegemonic institution of law enforcement" (Munt 85)? Black women have fared better, seemingly more able to bring new voices to the genre by creating original, less stereotyped characters. ${ }^{4}$ Haywood's fiction is very much anchored in this new trend initiated by women writers in the 80's in which the main hero, the P. I., abandons some of his/her Super(wo)man characteristics to become a more "normal" person. There is a semblance of normalcy in the lives of some characters in Haywood's fiction: friendly 
neighbours gossiping at Mickey's barbershop, Gunner's girlfriends (even though their lives are touched by tragedy at some point). Even Gunner sometimes just hangs out at the Acey Deuce bar, simply to pass the time. Poverty is still there, in this part of the city Haywood writes about, and affects people of all colours. But, in other parts of the city, life can be led normally, in diverse ethnic communities. Some black people lead affluent lives as entertainers or business people; Gunner catches a first-class flight to Chicago to see his beloved in the sixth novel.

Like many of his contemporaries (men and women), Haywood uses the novel as a forum for social critique, mostly issues dealing with the question of race, as seen through the main protagonist. In Haywood's books, Gunner is the main interest. We access the other characters, gangbangers and rappers, religious figures and dope dealers, prostitutes and wife-beaters solely through his questioning and reflections, which echo, as we have seen earlier, that of the author. The criminal elements in his novels are created "from scratch: pimps and crack dealers don't happen to be among [his] inner circle of friends. Still, growing up in a predominantly black, inner-city neighbourhood, one manages to pick up their language and mannerisms almost by osmosis, even from a safe distance" (Bailey 123). By adopting the conventions of the genre as defined by his white predecessors (the Chandler-Hammett-MacDonald tradition), Haywood can appeal to a wide, multi-ethnic audience who recognize an archetypal figure when they see one and feel safe even while reading about violence and death. At the same time, they are given food for thought. The Gunner series, with its running commentary on human relations, its attempt at giving a balanced view of the various aspects of a question, adds an element of reflexion, anchored in realism, to a literary genre too often content with just telling a mere adventure story.

\section{BIBLIOGRAPHY}

Bailey, Frankie Y. Out of the Woodpile: Black characters in Crime and Detective Fiction. Westport: Greenwood Press, 1991.

Baker, Nikki. In the Game. Tallahassee: The Naiad Press, 1991.

Bland, Eleanor Taylor. Dead Time. New York: Signet Books, 1992.

Décuré, Nicole. "In Search of our Sisters' Mean Streets: The Politics of Sex, Race and Class in Black Women's Crime Fiction." In Diversity and Detective Fiction: Race, Gender, Ethnicity. Ed. Kathleen G. Klein. Bowling Green: Bowling Green UP, 1999. 158-185.

Décuré, Nicole. "Noires et noir." Polar et féminisme, Actes de la Journée de l'ANEF (Association nationale des études féministes) 2000. Supplément au Bulletin de l'ANEF 35 (2001): 83-9.

Haywood, Gar Anthony. All the Lucky Ones Are Dead. New York: G.P. Putman's Sons, 1999.

Haywood, Gar Anthony. Fear of the Dark. New York: Penguin Books, 1988.

Haywood, Gar Anthony. Not Long for this World. New York: Penguin Books, 1990. 
Haywood, Gar Anthony. You Can Die Trying. New York: Penguin Books, 1993.

Haywood, Gar Anthony. It's not a Pretty Sight. New York: Berkley Prime Crime, 1996.

Haywood, Gar Anthony. When Last Seen Alive. New York: Berkley Prime Crime, 1997.

Haywood, Gar Anthony. "Smoke signals.” L. A. Weely, 24 April 2002. https://www.laweekly.com/ smoke-signals/

Haywood, Gar Anthony. The official website of Gar Anthony Haywood. https://

garanthonyhaywood.com/

Himes, Chester. Cotton Comes to Harlem. London: Panther Books, 1965.

Himes, Chester. For Love of Imabelle. New York: Dell, 1957.

Joe, Yolanda. Falling Leaves of Ivy. Stamford: Longmeadow, 1992.

Jordan, Jon. "Interview with Gar Anthony Haywood aka Ray Shannon." Mystery One Bookstore, Milwaukee 2003. http://www.mysteryone.com/interview.php?ID=701 [archived: https:// web.archive.org/web/20080514052844/http://www.mysteryone.com/ GarHaywoodInterview.htm]

Julien, Claude \& Alice Mills, eds. "Round Table Discussion: Paula Woods, Gar Haywood, Barbara Neely and Participants in the Symposium". "Polar noir:" Reading African-American Detective Fiction. Tours: Presses Universitaires François-Rabelais, 2005: 117-129.

Mosley, Walter. Devil in a Blue Dress. New York: Norton, 1990.

Munt, Sally. Murder by the Book? Feminism and the Crime Novel. London: Routledge, 1994.

Neely, Barbara. Blanche on the Lam. New York: Saint Martin's Press, 1992.

Soitos, Stephen F. The Blues Detective. A Study of African American Detective Fiction. Amherst: U. of Massachusetts P., 1996.

\section{NOTES}

1. Pauline Hopkins published Hagar's Daughter in 1900 and Rudolph Fisher The Conjure-Man Dies in 1932.

2. Private correspondence between the author of the article and Haywood, 13 June 2009.

3. P. I. fiction is that branch of crime fiction or detective fiction in which the hero/heroine is a private investigator. It usually runs in series, with the P. I. as recurrent hero/heroine.

4. For in-depth portraits of these heroines, see Décuré $(1999,2001)$.

\section{ABSTRACTS}

Gar Anthony Haywood is the first African American writer, forty years after Chester Himes, to write a crime fiction series with a black hero. The main character is a rather conventional P. I. but the novels stand out because of the running commentary on issues of race, violence, sexism, and homophobia. 
Quarante ans après Chester Himes, Gar Anthony Haywood est le premier écrivain africainaméricain à écrire une série policière dont le héros est noir. Le personnage principal est un détective privé plutôt conventionnel mais les romans se distinguent par leurs commentaires sur des questions de race, de violence, de sexisme et d'homophobie.

INDEX

Keywords: crime fiction, African American, racism, violence, Haywood Gar Anthony, literature, noir

Mots-clés: fiction policière, africain-américain, racisme, violence, Haywood Gar Anthony, littérature, polar

AUTHOR

NICOLE DÉCURÉ

Nicole Décuré is a French Emeritus professor at Toulouse University. Her fields of research are learning and teaching English as a foreign language and crime fiction. Contact: nicole.decure [at] univ-tlse3.fr 